\title{
Analisis Profil Penggunaan Layanan Peer-to-peer Lending Pada UKM di Kota Salatiga
}

\author{
Hendry Melvin Anindita dan Ika Kristianti \\ Program Studi Akuntansi, Fakultas Ekonomika dan Bisnis, \\ Universitas Kristen Satya Wacana Salatiga, Indonesia
}

E-Mail: 232016297@student.uksw.edu,ika.kristianti@uksw.edu
Lending Services and Small Medium

Enterprises

205

Submitted: AGUSTUS 2020

Accepted: NOVEMBER 2020

\begin{abstract}
The COVID-19 pandemic in Indonesia has inflicted an inevitable income drop to many businesses, including Small Medium Enterprise (SME). In order to continue running their operational activities and keep fulfilling its obligations, some SMEs started to use P2P lending services as one of its capital sources. The purpose of this study is to portray the profile of $P 2 P$ lending user, especially in Salatiga. This research is conducted by using qualitative research methodology with descriptive approach. Some SMEs believe that P2P lending can provide them with support in fulfilling their obligations. But in the other hand, there are others which argue that the services provided by P2P lending are inefficient and ineffective in fulfilling their business obligations.
\end{abstract}

Keywords: P2P lending, SMEs, Fulfillment of obligations

\begin{abstract}
ABSTRAK
Pandemi COVID-19 di Indonesia membuat sejumlah usaha mengalami penurunan pendapatan, tak terkecuali bagi para pelaku UKM. Agar dapat terus menjalankan kegiatan operasional dan memenuhi kewajibannya, beberapa UKM mulai menggunakan layanan $P 2 P$ lending sebagai salah satu sumber modalnya. Tujuan dari penelitian ini adalah untuk memberikan potret mengenai profil penggunaan layanan $P 2 P$ lending khususnya di kota Salatiga. Penelitian ini menggunakan tipe penelitian kualitatif dengan pendekatan deskriptif. Penggunaan layanan $P 2 P$ lending bagi beberapa pemilik UKM di kota Salatiga dirasa dapat membantu dalam pemenuhan kewajibannya, namun ada beberapa UKM yang berpendapat bahwa penggunaan layanan P2P lending tidak efisien dan efektif untuk pemenuhan kewajiban usahanya.
\end{abstract}

Kata kunci: P2P lending, Pelaku UKM, Pemenuhan kewajiban

\section{PENDAHULUAN}

Salah satu penggerak utama pertumbuhan perekonomian Indonesia adalah Usaha Kecil Menengah (UKM). UKM telah berkontribusi dalam sektor ekonomi bukan hanya karena mampu menyebar secara luas di daerah pedesaan, tetapi juga karena kemampuan UKM dalam menampung tenaga kerja dengan jumlah yang besar (Rosavina, Rahadi, Kitri, Nuraeni, \& Mayangsari, 2019). Menurut Badan Pusat Statistik (BPS), mengartikan Usaha Kecil Menengah (UKM) menurut jumlah karyawannya, dimana Usaha Mikro adalah bisnis yang mempekerjakan 1-4 orang, Usaha Kecil adalah bisnis yang mempekerjakan 5-19 orang, sedangkan Usaha Menengah adalah bisnis yang

\section{JIMKES}

Jurnal Ilmiah Manajemen Kesatuan 8 No. 3,2020 pp. $205-212$
IBI Kesatuan IBI Kesatuan
ISSN $2337-7860$ E-ISSN $2721-169 \mathrm{X}$ 
Lending Services and Small Medium Enterprises mempekerjakan 20-99 orang (Rosavina et al., 2019). UKM menurut Keputusan Presiden RI no. 99 tahun 1998 adalah kegiatan ekonomi rakyat yang berskala kecil dengan bidang usaha yang secara mayoritas merupakan kegiatan usaha kecil dan perlu dilindungi untuk mencegah dari persaingan usaha yang tidak sehat. Menurut Hidayah \& Muntiah (2019) UKM didefinisikan sebagai kegiatan usaha kecil yang dibentuk atas inisiatif seseorang. Pada akhir tahun 2019 dan sampai sekarang mendekati akhir tahun 2020, dunia diguncang dengan menyebarnya virus yang bernama Coronavirus disease-2019 atau yang sering disingkat COVID-19. Ketika menyerang manusia virus ini akan menyebabkan gangguan pada sistem pernafasan. Menurut data Google News (2020) sampai 05 Oktober 2020 pukul 22.00 WIB dilaporkan terdapat 303.498 kasus positif di Indonesia, dengan jumlah kematian mencapai 11.151 jiwa.

Salah satu pihak yang terkena dampak serius pandemi COVID-19 adalah para pelaku UKM di Indonesia. Menurut data Kementerian Koperasi, sebanyak 1.785 koperasi dan 163.713 pelaku UKM terdampak virus COVID-19. Mayoritas koperasi yang terdampak COVID-19 adalah koperasi yang bergerak di bidang kebutuhan sehari-hari, sedangkan untuk UKM yang paling merasakan dampak adalah pada sektor makanan dan minuman (Amri, 2020). Dalam situasi pandemi ini, sebanyak 37.000 UKM melaporkan bahwa mereka sangat merasakan dampak yang serius akibat pandemi ini, ditandai dengan laporan penurunan penjualan sebesar 56 persen, laporan permasalahan pada aspek pembiayaan sebesar 22 persen, laporan masalah distribusi barang sebesar 15 persen dan laporan kesulitan mendapatkan bahan baku mentah sebesar 4 persen. Masalah-masalah diatas dapat bertambah buruk jika dikaitkan dengan diberlakukannya kebijakan Pembatasan Sosial Berskala Besar (PSBB) yang diterapkan di beberapa wilayah di Indonesia (Pakpahan, 2020).

Perkembangan potensi UKM di Indonesia tidak diikuti dengan kondisi keuangan yang baik. Survei dari Badan Pusat Statistik (BPS) mengatakan, pendanaan menjadi masalah utama bagi para pelaku UKM. Mayoritas dari mereka tidak memenuhi persyaratan untuk mengajukan pinjaman di bank konvensional. Sementara sisanya lebih memilih sumber pendanaan lainnya, seperti tabungan. Hal inilah yang menyebabkan mereka kesulitan dalam memenuhi kewajiban jangka pendeknya.

Menurut data Kementerian Koordinator Bidang Perekonomian, dari Agustus 2015 hingga 31 Mei 2019 total realisasi penyaluran Kredit Usaha Rakyat (KUR) mencapai nilai Rp398,9 triliun. Nilai tersebut meliputi outstanding sebesar Rp149,5 triliun dan non performing loan (NPL) sebesar 1,35 persen. Penyaluran KUR tersebut mayoritas untuk skema KUR Kecil sebesar 34,58 persen. Lalu diikuti skema KUR Mikro 65,1 persen sementara sisanya untuk KUR tenaga kerja Indonesia dengan nilai 0,35 persen. Proporsi likuiditas di Indonesia belum seimbang, yakni untuk UKM hanya sebesar 20 persen dan 80 persen untuk usaha besar (Antaranews.com, 2019). Likuiditas dapat diartikan sebagai kesanggupan sebuah perusahaan dalam memenuhi kewajiban jangka pendeknya (Novita \& Sofie, 2015). Jangka pendek secara umum dianggap periode kurang dari satu tahun. Hal ini terkait dengan siklus operasi normal suatu perusahaan, yaitu mulai dari pembelian-produksi-penjualan-penagihan. Munawir (2010) berpendapat bahwa likuiditas adalah kapabilitas perusahaan untuk memenuhi kewajiban keuangannya yang harus segera dibayarkan. Likuiditas didefinisikan sebagai pemenuhan kewajiban jangka pendek menggunakan ketersediaan sumber kas perusahaan (Subramanyam, 2014). Risiko likuiditas jangka pendek suatu perusahaan dipengaruhi oleh waktu arus kas masuk dan keluar bersamaan dengan prospeknya untuk kinerja masa depan.

Seiring dengan perkembangan teknologi informasi, berkembang berbagai aplikasi yang berkaitan dengan keuangan. Perkembangan aplikasi tersebut adalah salah satunya Financial Technology (FinTech), layanan peer-to-peer lending (P2P lending). Menurut Sukmaningsih (2018) P2P lending merupakan proses peminjaman uang dimana orang yang akan meminjam dan orang yang akan memberi pinjaman bertemu melalui layanan internet tanpa memerlukan lembaga keuangan yang sah, termasuk bank. Menurut Bachmann et al. (2011) P2P lending merupakan layanan keuangan yang mengadaptasi 
model lama peminjaman dana menjadi pinjaman yang berbasis online. Dimana mediasi oleh lembaga keuangan tidak dibutuhkan. Rosavina et al. (2019) menjelaskan bahwa para peminjam menjelaskan masalah keuangan mereka, lalu para pemberi pinjaman akan menilai risiko dari bisnis peminjam dan akan memberi kesempatan untuk memilih preferensi untuk pendanaan mereka. Menurut Sukmaningsih (2018) terdapat dua jenis $P 2 P$ lending, yaitu komersial dan non-komersial. Pemberi pinjaman pada $P 2 P$ lending nonkomersial tidak mengharapkan keuntungan. Biasanya, tipe $P 2 P$ lending seperti ini memiliki tujuan membiayai orang-orang yang kurang mampu. Sementara pemberi pinjaman pada $P 2 P$ lending komersial, mengharapkan keuntungan dan bunga dari transaksi peminjaman.

Sistem kerja P2P lending ini mirip dengan konsep marketplace online, dimana terdapat wadah yang disediakan untuk tempat bertemunya pembeli dengan penjual. Dapat dikatakan $P 2 P$ lending merupakan marketplace untuk kegiatan pinjam-meminjamkan uang. Proses $P 2 P$ lending dapat dilihat dari dua sudut. Yang pertama sudut peminjam, dimulai dari mengunggah dokumen yang diperlukan secara online, biasanya berisi laporan keuangan jangka waktu tertentu dan tujuan peminjam. Langkah selanjutnya hanya menunggu permintaan pinjaman diterima atau ditolak. Jika ditolak, peminjam harus memperbaiki hal-hal yang dikoreksi oleh sistem P2P lending. Jika diterima, sistem akan menerapkan suku bunga pinjaman dan permohonan peminjam akan dimasukkan ke dalam marketplace yang tersedia. Sudut kedua adalah sebagai investor atau pemberi pinjaman. Investor dapat melihat data pengajuan pinjaman, seperti data pendapatan, riwayat keuangan, dan tujuan peminjaman dari peminjam. Jika investor setuju untuk menginvestasikan pinjaman tertentu, investor dapat langsung menginvestasikan sesuai tujuan investasinya.

Model pembiayaan menggunakan layanan $P 2 P$ lending ini akan lebih mengembangkan UKM karena akan memberikan banyak peluang kepada investor dari berbagai kalangan untuk mendanai usaha mereka. Kebanyakan UKM masih menggunakan pembiayaan melalui perbankan dan lembaga keuangan lainnya. Model pembiayaan P2P lending di beberapa negara dapat mengembangkan usahanya dengan kemudahan dalam melakukan peminjaman, tak terkecuali di Indonesia, beberapa perusahaan yang bergerak di bidang $P 2 P$ lending berhasil membantu pembiayaan UKM dan menciptakan lapangan kerja baru bagi lingkungan sekitarnya (Andini, 2017).

Hingga Agustus 2019, berdasarkan data Otoritas Jasa Keuangan (OJK) pinjaman sebesar Rp54,71 triliun telah tersalurkan oleh lembaga P2P lending yang terdaftar, atau meningkat sebesar 141,40 persen dari Desember 2018 secara year to date. Sekitar 60 persen peminjam $P 2 P$ lending yang berasal dari sektor UKM, memiliki ticket size yang beragam, mulai dari ratusan ribu untuk modal toko-toko penjual pulsa, hingga miliaran rupiah untuk usaha menengah dengan menggunakan skema invoice financing (Kontan.co.id, 2019). Menurut OJK, kebutuhan pendanaan di sektor UKM sudah mencapai jumlah Rp1.649 triliun, sementara kapasitas pendanaan yang dapat disediakan oleh jasa keuangan baru mencapai Rp660 triliun. Celah inilah yang dimanfaatkan P2P lending untuk membantu para pelaku UKM.

Persoalan penelitian ini adalah bagaimana profil penggunaan $P 2 P$ lending UKM khususnya di kota Salatiga? Tujuan penelitian ini untuk memberikan potret profil penggunaan $P 2 P$ lending UKM terutama di kota Salatiga. Manfaat penelitian ini diharapkan dapat memberi kontribusi ilmiah pada kajian tentang profil penggunaan $P 2 P$ lending UKM di kota Salatiga.

\section{METODE PENELITIAN}

Penelitian ini menggunakan tipe penelitian kualitatif dengan pendekatan deskriptif untuk menganalisis bagaimana profil penggunaan P2P lending pada UKM di kota Salatiga. Data yang digunakan dalam penelitian ini adalah data primer. Data primer akan didapatkan dengan cara melakukan wawancara kepada responden secara langsung, yaitu
Lending Services and Small Medium Enterprises 
Lending Services and Small Medium Enterprises

\section{8}

dengan mendatangi satu persatu calon responden, dan menanyakan kesediaannya untuk dokumentasi. Responden dapat memberikan pendapat terhadap setiap pertanyaan yang diberikan.

Responden dalam penelitian ini adalah 4 pemilik Usaha Kecil Menengah (UKM) yang berada di Kota Salatiga, masing-masing adalah AFTERLIFE CLOTHING.CO, Entingenting Gepuk Cap Klenteng \& 2 Hoolo cabang Senjoyo, Enting-enting Gepuk Cap Klenteng \& 2 Hoolo cabang Kalibening, dan Weny Kitchen. Kriteria pemilihan responden dalam penelitian ini adalah UKM yang menggunakan layanan P2P lending.

Penelitian ini terdiri dari beberapa tahapan, diantaranya (1) perumusan masalah yaitu bagaimana profil penggunaan $P 2 P$ lending UKM khususnya di kota Salatiga, (2) pengumpulan data melalui wawancara dan dokumentasi, (3) analisis data menggunakan teknik analisis triangulasi sumber dan (4) penarikan kesimpulan dari data yang diperoleh dan sudah dianalisis. Dalam penelitian ini, peneliti menggunakan teknik triangulasi sumber. Triangulasi sendiri merupakan teknik pengumpulan data yang menggabungkan data dari berbagai teknik pengumpulan data dan sumber data yang telah ada (Sugiyono, 2016). Sementara triangulasi sumber adalah triangulasi yang membandingkan keabsahan data yang diperoleh melalui sumber yang berbeda.

\section{HASIL DAN PEMBAHASAN Profil Responden}

Responden yang pertama adalah AFTERLIFE CLOTHING.CO, yaitu salah satu usaha kecil menengah (UKM) yang didirikan sejak tahun 2013 dan beralamat di Jl. Hasanudin No. 07, Salatiga. Usaha ini bergerak di bidang clothing line dengan memproduksi desain fashion sendiri. Responden yang kedua dan ketiga adalah Entingenting Gepuk Cap Klenteng \& 2 Hoolo cabang Senjoyo dan cabang Kalibening. Usaha Enting-enting Gepuk Cap Klenteng \& 2 Hoolo cabang Senjoyo didirikan pada tahun 1964 dan beralamatkan di Jl. Senjoyo No. 33, Kutowinangun Kidul, Salatiga. Usaha ini bergerak di bidang makanan khas Salatiga yaitu enting-enting gepuk. Enting-enting Gepuk Cap Klenteng \& 2 Hoolo cabang Kalibening juga bergerak di bidang makanan khas Salatiga enting-enting gepuk. Usaha ini didirikan pada tahun 2007 dan beralamatkan di Perumahan Bumi Tegalsari, J1. Ja'far Shodiq, Kalibening, Salatiga. Responden keempat adalah Weny Kitchen, yaitu UKM yang bergerak di bidang kuliner. Usaha ini didirikan pada tahun 2018 dan beralamatkan di Jl. Serang no 76A, Salatiga.

\section{Penggunaan Layanan P2P Lending}

Pemilik UKM AFTERLIFE CLOTHING.CO menggunakan layanan P2P lending sebagai salah satu sumber modalnya. Hal ini dikarenakan beliau membutuhkan dana untuk usahanya secara mendesak. Pemilik AFTERLIFE CLOTHING.CO mengaku memiliki pemahaman tentang layanan $P 2 P$ lending, tetapi beliau tidak terlalu menghafal regulasi peminjaman. Beliau juga memahami adanya risiko menggunakan layanan $P 2 P$ lending ini, yaitu dikejar-kejar oleh debt collector secara tidak sopan. Risiko lain yang dirasakan oleh beliau adalah dikenakannya bunga yang tinggi jika terlambat melakukan pembayaran.

Pemilik AFTERLIFE CLOTHING.CO mengaku bahwa penggunaan layanan $P 2 P$ lending dapat membantu pemenuhan kewajiban pada usahanya. Beliau berpendapat bahwa penggunaan pinjaman $P 2 P$ lending lebih efektif dibandingkan pinjaman bank konvensional, tetapi secara efektivitas beliau mengatakan belum tentu $P 2 P$ lending lebih baik. Selain menggunakan layanan P2P lending, pemilik AFTERLIFE CLOTHING.CO juga menggunakan pinjaman bank konvensional untuk usahanya. Beliau menggunakan keduanya karena membutuhkan lebih banyak dana untuk usahanya.

UKM Enting-enting Gepuk Cap Klenteng \& 2 Hoolo cabang Senjoyo juga menggunakan layanan P2P lending sebagai salah satu sumber modalnya. Pemilik Entingenting Gepuk Cap Klenteng \& 2 Hoolo cabang Senjoyo mengatakan, alasan digunakannya $P 2 P$ lending sebagai sumber modal untuk usaha beliau adalah karena beliau membutuhkan dana tambahan yang mendesak dikarenakan pendapatan yang menurun 
akibat pandemi virus COVID-19. Hal ini dilakukan agar proses produksi tetap berjalan dan tetap mampu membayar gaji pegawai. Pemilik Enting-enting Gepuk Cap Klenteng \& 2 Hoolo cabang Senjoyo mengaku bahwa beliau memiliki pemahaman tentang layanan $P 2 P$ lending, lalu beliau juga mengatakan bahwa beliau lumayan memahami regulasi peminjaman pada layanan $P 2 P$ lending. Pemilik Enting-enting Gepuk Cap Klenteng \& 2 Hoolo cabang Senjoyo memahami adanya risiko dalam penggunaan layanan $P 2 P$ lending yaitu dikenakannya bunga yang besar kalau telat membayar.

Pemilik Enting-enting Gepuk Cap Klenteng \& 2 Hoolo cabang Senjoyo mengatakan, penggunaan layanan $P 2 P$ lending pada usaha beliau dapat membantu pemenuhan kewajiban usahanya. Beliau juga berpendapat bahwa layanan P2P lending lebih efektif dan efisien dibandingkan dengan kredit pada bank konvensional. Alasan beliau lebih memilih menggunakan layanan P2P lending dibandingkan kredit pada bank konvensional adalah karena proses peminjaman pada $P 2 P$ lending lebih mudah. Selain itu, karena kebutuhan dana tambahan yang mendesak, $P 2 P$ lending lebih dipilih karena proses pencairan dananya lebih cepat.

UKM Enting-enting Gepuk Cap Klenteng \& 2 Hoolo cabang Kalibening juga menggunakan P2P lending sebagai salah satu sumber modalnya. Kebutuhan dana tambahan untuk membayar kewajiban menjadi alasan pemilik Enting-enting Gepuk Cap Klenteng \& 2 Hoolo cabang Kalibening menggunakan peminjaman P2P lending. Pemilik Enting-enting Gepuk Cap Klenteng \& 2 Hoolo cabang Kalibening mengatakan bahwa beliau memiliki pemahaman tentang $P 2 P$ lending tetapi tidak terlalu memahami regulasi peminjamannya. Beliau juga sadar akan adanya risiko penggunaan $P 2 P$ lending yaitu masa pengembalian pinjaman yang pendek dan bunga yang cukup besar. Penggunaan P2P lending dirasa oleh pemilik Enting-enting Gepuk Cap Klenteng \& 2 Hoolo cabang Kalibening sangat membantu untuk membayar kewajiban usaha, apalagi di saat pandemi seperti sekarang dimana pendapatan usaha beliau lumayan menurun. Beliau juga mengatakan bahwa P2P lending lebih efektif dan efisien dibandingkan dengan bank konvensional. Tetapi, beliau juga menggunakan pinjaman bank konvensional karena beliau masih membutuhkan dana tambahan untuk tetap melaksanakan proses produksi.

Pemilik Weny Kitchen pernah menggunakan layanan P2P lending pada tahun 2018, namun beliau berhenti menggunakan layanan $P 2 P$ lending karena dirasa kurang efisien untuk membantu pendanaan usaha beliau. Pemilik Weny Kitchen mengaku tidak memiliki pemahaman tentang apa itu $P 2 P$ lending juga tentang regulasinya. Beliau mengatakan adanya risiko penggunaan layanan $P 2 P$ lending yaitu jumlah bunga yang terlalu besar. Lalu bila ada keterlambatan pembayaran, dikenakan denda yang lumayan besar yaitu sebesar $40 \%$ dari nominal pinjaman. Pemilik Weny Kitchen mengaku, penggunaan layanan $P 2 P$ lending tidak dapat membantu pemenuhan kewajiban pada usaha beliau. Beliau juga berpendapat, penggunaan layanan $P 2 P$ lending tidak lebih efektif dan efisien dibandingkan dengan pinjaman bank konvensional.

\section{Pembahasan}

Latar belakang tiga responden pertama menggunakan layanan $P 2 P$ lending adalah kebutuhan dana yang sangat mendesak dan cepat. Hal tersebut sejalan dengan pendapat Rumondang (2018), yaitu dalam layanan P2P lending jika peminjam telah memenuhi syarat, peminjam dapat mencairkan pinjaman dalam waktu beberapa hari. Hal ini lebih efektif dibandingkan dengan mengajukan pinjaman pada lembaga keuangan bank konvensional yang membutuhkan waktu sekitar 1 bulan untuk mencairkan dana pinjaman. Menurut Rizal et al. (2018) layanan keuangan dapat menjadi murah, cepat, dan mudah berkat kehadiran teknologi. Ketiga elemen tadi sulit didapatkan ketika pelaku UKM mendatangi bank. Mukhtar (2018) berpendapat bahwa pada proses pengajuan pinjaman bank konvensional terdapat banyak berkas administrasi yang harus dibuat dan dilengkapi, sedangkan pada P2P lending kelengkapan berkas yang harus dilengkapi sangat sedikit dan bahkan calon peminjam hanya perlu meng-upload berkas tadi secara online. Proses yang simpel itulah yang membuat layanan P2P lending dianggap lebih efisien dan efektif dibandingkan pinjaman bank konvensional.
Lending Services and Small Medium Enterprises

209 
Lending Services and Small Medium Enterprises
P2P lending hadir untuk memberikan solusi terhadap permasalahan "the missing middle" pada masyarakat dan UKM yang memiliki potensi berkembang namun tidak memiliki akses pendanaan yang memadai. Dengan adanya $P 2 P$ lending, pelaku UKM akan dibantu untuk mendapatkan akses keuangan. $P 2 P$ lending juga dapat menjadi jembatan antara UKM yang tadinya belum terjamah institusi keuangan dengan UKM yang sudah bankworthy, sehingga mereka dapat menjadi bankworthy di waktu yang akan datang. Tidak hanya sebatas membantu pembiayaan usaha, namun peran $P 2 P$ lending juga merambah ke berbagai aspek, seperti layanan pembayaran secara digital dan pengelolaan keuangan yang kedepannya akan bermanfaat bagi pelaku UKM dalam membesarkan usahanya (Rumondang, 2018).

Namun, bagi beberapa UKM layanan $P 2 P$ lending dirasa tidak efisien dan efektif dalam membantu pemenuhan kewajiban usaha mereka, salah satu yang merasakan hal tersebut adalah pemilik Weny Kitchen. Bunga yang besar dan juga denda keterlambatan yang besar menjadi alasan pemilik Weny Kitchen berhenti menggunakan layanan P2P lending. Hal ini sejalan dengan pernyataan Research Officer UKM Indonesia, Banu Rinaldi, yaitu kekurangan dari layanan P2P lending adalah suku bunga pinjaman yang dapat melonjak naik saat kelayakan kredit dirasa buruk. Lalu, jumlah yang harus dibayar dapat naik secara signifikan akibat keterlambatan atau kegagalan pembayaran. Jadi, pinjaman model seperti ini tidak cocok untuk pinjaman untuk jangka panjang, karena semakin lama jangka waktu pembayaran, jumlah tagihan akan semakin besar (Ukmindonesia.id, 2020)

\section{PENUTUP}

Tujuan dari penelitian ini adalah untuk memberikan potret mengenai profil penggunaan layanan P2P lending UKM terutama di kota Salatiga. Sehingga, berdasarkan hasil analisis yang telah dijelaskan dapat dikatakan bahwa layanan P2P lending dapat membantu pemenuhan kewajiban pada mayoritas bisnis UKM di kota Salatiga. Kemudahan proses pengajuan pinjaman dan jangka waktu pencairan yang singkat menjadi alasan utama dipilihnya layanan $P 2 P$ lending sebagai salah satu modal usaha mereka dibandingkan pinjaman pada bank konvensional. Apalagi di saat pandemi seperti sekarang, dimana semua pendapatan usaha menurun, para pemilik UKM harus tetap menjalankan kegiatan operasional usahanya dan tetap membayar gaji para pegawainya. Namun pada beberapa UKM di kota Salatiga, layanan P2P lending dirasa tidak efektif dan efisien dalam membantu pemenuhan kewajiban usaha mereka. Hal ini diakibatkan oleh tingkat bunga yang cukup tinggi dan denda keterlambatan yang lumayan besar, sehingga dirasa kurang membantu dalam pemenuhan kewajiban usaha mereka.

\section{DAFTAR PUSTAKA}

[1] Amri, A. (2020). Dampak Covid-19 Terhadap UMKM di Indonesia. Jurnal Brand, 2(1), 147-153. Retrieved from https://www.academia.edu/42672824/Dampak_Covid19_Terhadap_UMKM_di_Indonesia

[2] Andini, G. (2017). Faktor-Faktor yang Menentukan Keputusan Pemberian Kredit Usaha Mikro Kecil dan Menengah (UMKM) pada Lembaga Keuangan Mikro Peer to Peer Lending. Jurnal Ekonomi Dan Bisnis Universitas Islam Negeri Syarif Hidayatullah. https://doi.org/10.1017/CBO9781107415324.004

[3] Bachmann, A., Funk, B., Becker, A., Buerckner, D., Hilker, M., Kock, F., ... Tiburtius, P. (2011). Online Peer-to-Peer Lending - A Literature Review. Journal of Internet Banking and Commerce, 16(2), 1-21.

[4] COVID-19 Deployment. https://news.google.com/covid19/map?hl=en-

(2020). Retrieved from $I D \& m i d=\% 2 F m \% 2 F 02 b d 41 \& g l=I D \& c e i d=I D \% 3 \mathrm{Aen}$

[5] Gendalasari, G.G., 2020. A Market-Based analysis On Small anda Medium Busines Strategies in Bogor's Footwear Industry. Riset, 2(1), pp.153-166.

[6] Hidayah, N., \& Muntiah, N. S. (2019). Persepsi Pelaku UKM Terhadap Laporan Keuangan Berdasarkan Standar Akuntansi Keuangan Entitas Tanpa Akuntanbilitas 
Publik (SAK ETAP). Jurnal Akuntansi Indonesia Universitas Muhammadiyah Ponorogo, 8(1), 39-55.

[7] Hidayat, L., Muktiadji, N. and Supriadi, Y., 2019. Pengaruh Pengetahuan Investasi Terhadap Minat Mahasiswa Berinvestasi Di Galeri Investasi Perguruan Tinggi. JASPT (Jurnal Analisis Sistem Pendidikan Tinggi Indonesia), 3(2), pp.63-70.

[8] Iriyadi, I., Maulana, M.A. and Nurjanah, Y., 2018, December. Financial Reporting for Micro Small and Medium Enterprises Towards Industrial Revolution Era 4.0. In International Conference On Accounting And Management Science 2018 (pp. 32-38).

[9] Mukhtar, D. F. (2018). Analisis Pendanaan Modal Umkm Melalui Financial Technology Peer To Peer Lending ( P2P ). Jurnal Ilmu Dan Riset Akuntansi Sekolah Tinggi Ilmu Ekonomi Indonesia (STIESIA) Surabaya, 8(5).

[10] Munawir, S. (2010). Analisis Laporan Keuangan. Yogyakarta : Liberty.

[11] Novita, B. A., \& Sofie. (2015). Pengaruh Struktur Modal dan Likuiditas terhadap Profitabilitas. E-Journal Akuntansi Trisakti, 2(1), 13-28.

[12] Nurendah, Y. and Rainanto, B.H., 2019, May. The Analysis of Shoes Marketing Mix in Style Successful Benefits SMEs of Shoes Product in Bogor. In 1st International Conference on Economics, Business, Entrepreneurship, and Finance (ICEBEF 2018). Atlantis Press.

[13] Pakpahan, A. K. (2020). Covid-19 Dan Implikasi Bagi Usaha Mikro, Kecil, Dan Menengah. Jurnal Ilmiah Hubungan Internasional Universitas Katolik Parahyangan, O(0), 59-64. https://doi.org/10.26593/jihi.v0i0.3870.59-64

[14] Purnama, S. (2019). KEIN Minta Perbankan Memudahkan Akses Likuiditas UMKM. (n.d.). Retrieved from https://www.antaranews.com/berita/1013326/kein-minta-perbankanmemudahkan-akses-likuiditas-umkm

[15] Pramiudi, U. and Setiawan, B., 2019. Penelusuran Persepsi Mahasiswa Atas Program Studi Akuntansi dan Minat Studi Lanjut. JAS-PT (Jurnal Analisis Sistem Pendidikan Tinggi Indonesia), 2(2), pp.103-113.

[16] Rainanto, B.H., 2019. Analisis Permasalahan Yang Dihadapi Oleh Pelaku Usaha Mikro Agar Berkembang Menjadi Usaha Kecil (Scalling Up) Pada Umkm Di 14 Kecamatan Di Kabupaten Bogor. Jurnal Ilmiah Manajemen Kesatuan, 7(1), pp.201210.

[17] Rinaldi, B. (2020). Peer-to-Peer (P2P) Lending, Alternatif Pembiayaan UMKM di Saat Krisis. Retrieved from https://www.ukmindonesia.id/baca-artikel/273

[18] Rizal, M., Maulina, E., \& Kostini, N. (2018). Fintech Sebagai Salah Satu Solusi Pembiayaan Bagi UMKM. Jurnal Pemikiran Dan Penelitian Administrasi Bisnis Dan Kewirausahaan Universitas Padjadjaran, 3(2), 89-100.

[19] Rosavina, M., Rahadi, R. A., Kitri, M. L., Nuraeni, S., \& Mayangsari, L. (2019). P2P lending adoption by SMEs in Indonesia. Qualitative Research in Financial Markets, 11(2), 260-279. https://doi.org/10.1108/QRFM-09-2018-0103

[20] Rosdiana, Y.M., Iriyadi, I. and Wahyuningsih, D., 2020. Pendampingan Peningkatan Efisiensi Biaya Produksi UMKM Heriyanto Melalui Analisis Biaya Kualitas. Jurnal Abdimas Dedikasi Kesatuan, 1(1), pp.1-10.

[21] Rumondang, A. (2018). The Utilization of Fintech (P2P Landing) as SME's Capital Solution in Indonesia: Perspective in Islamic Economics (Qirad). International Conference of Moslem Society Trisakti University, 2, 12-22. https://doi.org/10.24090/icms.2018.1818

[22] Subramanyam, K. R. (2014). Financial Statement Analysis, Eleventh Edition. Published by McGraw-Hill Education. https://doi.org/10.1017/CBO9781107415324.004

[23] Sugiyono. (2016). Metode Penelitian Kuantitatif, Kualitatif dan R\&D. 1(4), 53.

[24] Sukmaningsih, D. W. (2018). A Model for Lender-Borrower Trust in Peer-To-Peer Lending. ComTech: Computer, Mathematics and Engineering Applications Binus University, 9(1), 15. https://doi.org/10.21512/comtech.v9i1.4287

[25] Sulistiono, S., Fadillah, A. and Putrie, D.E., 2020, May. Factors Affecting Bogor
Lending Services and Small Medium Enterprises 
Lending Services and Small Medium Enterprises

\section{2}

Botanical Garden Visitors' Intention Before and After the One Way System Application. In 2nd International Seminar on Business, Economics, Social Science and Technology (ISBEST 2019) (pp. 291-296). Atlantis Press.

[26] Walfajri, M. (2019). AFPI: Sebanyak 60\% peminjam fintech berasal dari sektor UMKM. (n.d.). Retrieved from Kontan.co.id website: https://keuangan.kontan.co.id/news/afpi-sebanyak-60-peminjam-fintech-berasaldari-sektor-umkm

[27] Wijaya, F. and Sujana, S., 2020. Pengaruh Kualitas Layanan Dan Persepsi Harga Terhadap Kepuasan Pelanggan Serta Dampaknya Terhadap Word Of Mouth. Jurnal Ilmiah Pariwisata Kesatuan, 1(1), pp.9-18.

[28] Zuhdi, S., Daud, A., Hanif, R., Nguyen, P.T. and Shankar, K., 2019. Role of Social Media Marketing in the Successful Implementation of Business Management. International Journal of Recent Technology and Engineering, 8. 